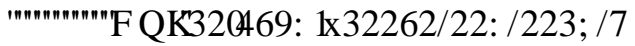

\title{
PRACTICAL METHOD FOR NUMERICAL EVALUATION OF PARAMETERS OF POOL FIRES IN OIL PIPELINE NETWORKS
}

\section{ПРАКТИЧЕСКИЙ МЕТОД ЧИСЛЕННОГО ОЦЕНКИ ПАРАМЕТРОВ ПОЖАРОВ РАЗЛИТИЯ НА МАГИСТРАЛЬНЫХ НЕФТЕПРОВОДНЫХ СЕТЯХ}

\author{
SELEZNEV Vadim, ALESHIN Vladimir \\ Joint Stock Company "Physical \& Technical Center" \\ e-mails: sve@ptc.sar.ru, sve@ptc.sar.ru
}

\begin{abstract}
This paper presents a method for numerical evaluation of parameters of flammable liquid pool fires caused by storage tank or pipeline failures. The method may be useful for specialists working in oil and gas, and chemical industries. It was successfully applied in fire safety analysis of Russian gas and oil processing facilities.
\end{abstract}

Keywords: Pool fire, Pipeline, Tank, Numerical simulation.

Содержание: В статье представлен практический метод численной оценки параметров пожаров разлития, возникающих при разрушениях резервуаров хранения или трубопроводов. Метод ориентирован на эксплуатацию специалистами газовой, нефтяной и химической промышленности. Он успешно применялся на объектах российской газовой и нефтяной промышленности.

Ключевые слова: пожары разлития, трубопровод, хранилище, численное моделирование. 


\section{PRACTICAL METHOD FOR NUMERICAL EVALUATION OF PARAMETERS OF POOL FIRES IN OIL PIPELINE NETWORKS}

\section{Statement of the problem}

This paper is a logical sequel to the description of practical methods for mathematical simulation of fires at gas and oil facilities, which methods were initially described in [6]. As is well known, combustion of liquid fuel spilled on the terrain adjacent to the region of pipeline (or storage tank) rupture takes place as combustion of a stream of its vapor in the air.

The stream of vapor in the flame is maintained by continuous evaporation. The rate of evaporation is determined by the rate of the heat flow coming from the flame to the liquid fuel. Oxygen required for combustion comes to the reaction zone from the ambient air. The flame of the combusting liquid fuel can be treated as a diffusion flame. Accordingly, for the purpose of simulation, it is advisable to consider liquid fuel combustion as a specific case of liquid evaporation accompanied by combustion of non-mingled gases (vapor and oxidant) [8].

High-accuracy simulation of pool fires is an extremely difficult task because of the complex and varied nature of the physical and chemical processes involved. As such processes, we can consider formation of a homometric layer in liquid fuel, boiling and evaporation of the fuel, its splashing, ignition and combustion of liquid fuel vapors.

Mechanisms of these processes may vary substantially, according to the type of fuel, the condition and type of the soil at the accident site, weather conditions, etc. This paper describes a method for numerical simulation of combustion of liquid fuels transmitted through pipelines and/or stored in tanks, with the aim of making estimative calculations of parameters of actual or potential pool fires.

Solving the problem, we proceed from an assumption that the liquid fuel spillage occurred on a porous terrain. Parameters of the spillage spot on the terrain are assumed to be known. On a first approximation, simulation conventionally disregards the phase of fuel warmup. The chemical reactions of combustion are assumed to be infinitely rapid. 


\section{Simulation of a fuel evaporation phase}

The liquid fuel evaporates into a gas phase, and a combustible mixture develops. In estimative simulation of fuel evaporation, the following simplifications and assumptions are admitted: (see. [8]):

- the fuel and the environment during evaporation are assumed to be in a quasistationary state;

- the processes of heat and mass transfer are assumed to be identical (the Lewis number being equal to one);

- with respect to the mixture of atmospheric air and fuel vapors, we assume that the heat conductivity coefficient $\lambda$ and the product of the mixture density $\rho$ and the coefficient of fuel vapors binary diffusion in the atmospheric air $D_{\text {vap }}$ are constant and not dependent on the temperature $T$;

- the specific heat of fuel vapors $c_{p}^{v a p}$ is assumed to be constant and not dependent on temperature;

- fuel vapors are assumed to be diffusing in the still air along the vertical coordinate axis $\mathrm{Oz}$ directed away from the center of the Earth;

- the magnitude of the diffusion mass flow $(J=\rho \cdot w)$ has finite value only with respect to fuel vapors, i.e., $J=J_{\text {vap }}$, where $w$ is the projection of an average velocity of the center of mass of the fuel vapors and atmospheric air mixture onto the coordinate axis $\mathrm{Oz}$ ( $w$ being the only non-zero projection of the velocity); usually, in the context of fluid mechanics, such a flow is called convective, whereas, in this case, its name has been changed in accordance with the physics of evaporation processes and the recommendations contained in [8];

- the shear stresses work and kinetic energy are negligible;

- there are no outside sources of energy in the fuel evaporation zone;

- the air is not dissolving in the fuel;

- no chemical reactions take place during evaporation.

Evaporation of the spilled liquid fuel is a version of the well known problem of the Stephen flow. To state and solve the problem, let us write down the continuity equation for liquid fuel vapor in the diffusion approximation subject to the admitted quasistationary nature of the evaporation process and the above assumptions: 


$$
\rho \cdot w \cdot \frac{d Y_{v a p}}{d z}-\rho \cdot D_{v a p} \cdot \frac{d^{2} Y_{v a p}}{d z^{2}}=0
$$

where $Y_{\text {vap }}$ is the relative mass fraction of fuel vapors; $z$ is the spatial coordinate on the vertical axis $\mathrm{Oz}$. As boundary conditions for this problem, we assume the following:

$$
\begin{aligned}
& \text { if } z=0: \quad Y_{\text {vap }}=Y_{\text {vap }, 0}=Y_{\text {vap }, \text { sat }} \\
& \text { if } z=l: \quad Y_{\text {vap }}=Y_{\text {vap }, l}=Y_{\text {vap }, \text { stoich }},
\end{aligned}
$$

where $z=0$ is the level of the liquid fuel free surface; $Y_{\text {vap,sat }}$ is the relative mass fraction of fuel vapors upon saturation; $z=l$ is the level of combustion front over the fuel; $l$ is the length of a gas layer between the liquid fuel free surface and the combustion front; $Y_{\text {vap } \text {, stoich }}$ is the known relative mass fraction of fuel vapors in their stoichiometric mixture with the air.

Let us make, subject to the admitted assumptions and simplifications, the first integration of the equation (1):

$$
\rho \cdot w \cdot Y_{\text {vap }}-\rho \cdot D_{\text {vap }} \cdot \frac{d Y_{\text {vap }}}{d z}=\text { const }=\rho \cdot w
$$

or

$$
\rho \cdot D_{\text {vap }} \cdot \frac{d Y_{\text {vap }}}{d z}=\rho \cdot w \cdot\left(Y_{\text {vap }}-1\right)
$$

The second integration of the equation (1) produces the following solution:

$$
\ln \left(Y_{\text {vap }}-1\right)=\frac{\rho \cdot w \cdot z}{\rho \cdot D_{\text {vap }}}+\text { const }
$$

The application of the boundary conditions (2) results in

$\ln \left(Y_{\text {vap,sat }}-1\right)=$ const 
and

$\ln \left(Y_{\text {vap }, \text { stoich }}-1\right)=\frac{\rho \cdot w \cdot l}{\rho \cdot D_{\text {vap }}}+$ const.

Then,

$\frac{\rho \cdot w \cdot l}{\rho \cdot D_{\text {vap }}}=\ln \left(\frac{1-Y_{\text {vap }, \text { stoich }}}{1-Y_{\text {vap }, \text { sat }}}\right)$.

Accordingly, the obtained evaluation of the diffusion mass flow of fuel vapors into the combustion zone looks as follows:

$J_{\text {vap }}=\rho \cdot w=\frac{\rho \cdot D_{v a p}}{l} \cdot \ln \left(\frac{1-Y_{\text {vap }, \text { stoich }}}{1-Y_{\text {vap }, \text { sat }}}\right)$.

Despite the explicitness of the above approach to simulating fuel evaporation processes, from the practical standpoint, the evaluation of the fuel vapor flow into the combustion zone (3) has a little appeal because of the complicated determination of parameters $l$ and $Y_{\text {vap,sat }}$. It should be emphasized here that the value $Y_{\text {vap,sat }}$ has a substantial effect on the evaporation process and depends on temperature [8]. For this reason, we shall obtain evaluation of the diffusion mass flow of fuel vapors into the combustion zone in a different way. Let us write down, subject to the above assumptions and simplifications, a modification of the well known energy equation [4]:

$-\lambda \cdot \frac{d^{2} T}{d z^{2}}+\rho \cdot w \cdot c_{p}^{\text {vap }} \cdot \frac{d T}{d z}=0$.

The first integration (4) produces:

$\lambda \cdot \frac{d T}{d z}-\rho \cdot w \cdot c_{p}^{v a p} \cdot T=-Q_{0}-\rho \cdot w \cdot c_{p}^{v a p} \cdot T_{0}$

or 


$$
\frac{d T}{d z}=\frac{1}{\lambda} \cdot\left[\rho \cdot w \cdot c_{p}^{v a p} \cdot\left(T-T_{0}\right)-Q_{0}\right]
$$

where $Q_{0}$ is the heat flow towards the fuel surface; $T_{0}$ is the temperature on the fuel surface.

After the second integration, we obtain:

$\ln \left[T-T_{0}-\frac{Q_{0}}{\rho \cdot w \cdot c_{p}^{\text {vap }}}\right]=\frac{\rho \cdot w \cdot c_{p}^{v a p} \cdot z}{\lambda}+$ const.

Substitution of boundary conditions (if $z=0: \quad T=T_{0}$ ) and (if $z=L: T=T_{L}$ ) allows us to write down:

const $=\ln \left[-\frac{Q_{0}}{\rho \cdot w \cdot c_{p}^{v a p}}\right] ; \quad \ln \left[1-\frac{c_{p}^{v a p} \cdot\left(T_{L}-T_{0}\right)}{Q_{0} / \rho \cdot w}\right]=\frac{\rho \cdot w \cdot c_{p}^{v a p} \cdot L}{\lambda}$,

where $L$ is a certain known distance in the computation domain.

It was noted before that on a first approximation we disregard the processes of fuel warmup. Then we can assume that, in the simulated pool fire, from the moment the fire starts and till the moment the spilled liquid fuel burns out, the liquid fuel free surface has the temperature equal to the boiling temperature $T_{\text {boil }}$ of this liquid fuel. This assumption is quite admissible, since, in the fuel warmup phase, energy is transferred to its surface layer until it reaches the boiling temperature [10]. The heat delivered to the liquid fuel from the ground and other flame-unrelated sources is disregarded in this case. Then it possible to write that $\left(Q_{0}=-\rho \cdot w \cdot q_{0}\right)$, where $q_{0}$ is the latent heat of fuel evaporation [8]. As a result, we obtain evaluation of the diffusion mass flow of fuel vapors into the combustion zone, in the following form:

$$
J_{\text {vap }}=\rho \cdot w=\frac{\lambda}{L \cdot c_{p}^{\text {vap }}} \cdot \ln \left[1+\frac{c_{p}^{\text {vap }} \cdot\left(T_{L}-T_{\text {boil }}\right)}{q_{0}}\right] \text {. }
$$

In the process of numerical solution of a problem by mesh methods, the temperature $T_{L}$ is generally associated with the time-variable temperature of the mixture of liquid fuel vapors and the air at the spatial computation 
mesh nods nearest to fuel surface on the gas phase side. In the computation, the heat conductivity coefficient $\lambda$ in (5) is substituted with the coefficient of effective heat conductivity computable by the reference data and methods described, for instance, in [4]. Values $c_{p}^{v a p}$ and $q_{0}$ are experimental reference data.

In pool fire simulation, formula (5) allows to make an upper evaluation of behavior parameters of the source of flammable vapors. Given the functional relationship of the diffusion mass flow of its vapors (5) is known, it is not difficult to estimate the time when the spilled liquid will have burned out. This estimate is required to forecast the duration of fire.

\section{Simulation of a phase of liquid fuel vapors combustion}

At this stage, we make numerical analysis of volatile vapors combustion parameters in the gas phase, treating it as a not pre-mingled gaseous mixture and using the approaches set forth in [6]. Here we use the turbulent eddy break-up model proposed by D.B. Spalding [8]. Subject to the above, simulation of the combustion phase (on the assumption of a single-stage irreversible index-recorded reaction between fuel vapors and the oxidant) is reduced to numerical analysis of the following set of equations $[6,7]$ :

$$
\begin{aligned}
& \frac{D \rho}{D t}+\rho \cdot(\vec{\nabla} \cdot \overrightarrow{\mathbf{V}})=0 ; \\
& \rho \cdot \frac{D Y_{\text {vap }}}{D t}=\vec{\nabla} \cdot\left(\frac{\mu+\mu_{T}}{\mathrm{Sc}_{\text {vap }}} \cdot \vec{\nabla} Y_{\text {vap }}\right)-\omega_{\text {vap }} ; \\
& \rho \cdot \frac{D Y_{\text {air }}}{D t}=\vec{\nabla} \cdot\left(\frac{\mu+\mu_{T}}{\mathrm{Sc}_{\text {air }}} \cdot \vec{\nabla} Y_{\text {air }}\right)-\xi_{\text {air }}^{\text {mass }} \cdot \omega_{\text {vap }} ; \\
& Y_{\text {prod }}=1-Y_{\text {vap }}-Y_{\text {air }} ; \\
& \omega_{\text {vap }}=\rho \cdot A \cdot \frac{\varepsilon}{K} \cdot \min \left(Y_{\text {vap }}, \frac{Y_{\text {air }}}{\xi_{\text {airs }}^{\text {mas }}}, \frac{B \cdot Y_{\text {prod }}}{1+\xi_{\text {air }}^{\text {mass }}}\right) ; \\
& \rho \cdot \frac{D \overrightarrow{\mathbf{V}}}{D t}=\left(\rho-\rho_{\text {atm }}\right) \cdot \overrightarrow{\mathbf{g}}-\vec{\nabla} P+\vec{\nabla} \cdot\left(\frac{\mu+\mu_{T}}{\mu} \cdot \boldsymbol{\tau}\right)-\frac{2}{3} \cdot \vec{\nabla}(\rho \cdot K) ; \\
& \rho \cdot \frac{D H}{D t}=\frac{\partial P}{\partial t}+Q_{\text {comb }} \cdot \omega_{\text {vap }}-S_{\text {rad }}+\frac{\partial Q}{\partial t}+\rho \cdot \overrightarrow{\mathbf{g}} \cdot \overrightarrow{\mathbf{V}}+
\end{aligned}
$$




$$
\begin{aligned}
& +\vec{\nabla} \cdot\left(\left(\lambda+\lambda_{T}\right) \cdot \vec{\nabla} T+\frac{\mu+\mu_{T}}{\mu} \cdot \boldsymbol{\tau} \cdot \overrightarrow{\mathbf{V}}-\frac{2}{3} \cdot \rho \cdot K \cdot \overrightarrow{\mathbf{V}}\right)+\sum_{m=1}^{N^{*}} \vec{\nabla} \cdot\left[e_{m} \cdot \frac{\mu+\mu_{T}}{S c_{m}} \cdot \vec{\nabla} Y_{m}\right] \\
& \rho \cdot \frac{D K}{D t}=\vec{\nabla} \cdot\left[\frac{\mu+\mu_{T}}{\operatorname{Pr}_{K}} \cdot \vec{\nabla} K\right]+G-\rho \cdot \varepsilon-\frac{\mu_{T}}{\rho \cdot \operatorname{Pr}_{T}} \cdot(\overrightarrow{\mathbf{g}} \cdot \vec{\nabla} \rho) ; \\
& \rho \cdot \frac{D \varepsilon}{D t}=\vec{\nabla} \cdot\left[\frac{\mu+\mu_{T}}{\operatorname{Pr}_{\varepsilon}} \cdot \vec{\nabla} \varepsilon\right]+\frac{\varepsilon}{K} \cdot\left(C_{2} \cdot G-C_{3} \cdot \rho \cdot \varepsilon-C_{1} \cdot \frac{\mu_{T}}{\rho \cdot \operatorname{Pr}_{T}} \cdot(\overrightarrow{\mathbf{g}} \cdot \vec{\nabla} \rho)\right) ; \\
& S_{\text {rad }}=\sum_{j=1}^{L^{*}} \varphi_{j}\left(Y_{j}\right) \cdot \int_{v=0}^{\infty} \vec{\nabla} \cdot \overrightarrow{\mathbf{q}}_{v, j}^{r} d v, \\
& \text { where } \vec{\nabla} \cdot \overrightarrow{\mathbf{q}}_{v, j}^{r}=\chi_{v, j} \cdot\left(4 \cdot \pi \cdot I_{v b}(T)-\int_{4 \cdot \pi} I_{v, j}(s, \overrightarrow{\boldsymbol{\theta}}, t) d \vartheta\right) \text {; } \\
& \frac{1}{c_{r a d}} \cdot \frac{\partial I_{v, j}(s, \overrightarrow{\boldsymbol{\theta}}, t)}{\partial t}+\overrightarrow{\boldsymbol{\theta}} \cdot \vec{\nabla} I_{v, j}(s, \overrightarrow{\boldsymbol{\theta}}, t)+\left(\chi_{v, j}+\beta_{v, j}\right) \cdot I_{v, j}(s, \overrightarrow{\boldsymbol{\theta}}, t)= \\
& =\chi_{v, j} \cdot I_{v b}(T)+\frac{\beta_{v, j}}{4 \cdot \pi} \cdot \int_{4 \cdot \pi} \gamma_{v, j}\left(\overrightarrow{\boldsymbol{\theta}}, \overrightarrow{\boldsymbol{\theta}}^{\prime}\right) \cdot I_{v, j}\left(s, \overrightarrow{\boldsymbol{\theta}}^{\prime}, t\right) d \vartheta^{\prime}, \quad j=\overline{1, L^{*}} ; \\
& P=\rho \cdot R \cdot T+\rho_{a t m} \cdot g \cdot\left(x_{3}-x_{3,0}\right) ; \quad R=R_{0} \cdot \sum_{m=1}^{N^{*}} \frac{Y_{m}}{M_{m}} ; \\
& H=C_{p} \cdot T+\frac{\overrightarrow{\mathbf{V}} \cdot \overrightarrow{\mathbf{V}}}{2} ; \quad \alpha=\alpha_{m i x}=\sum_{m=1}^{N^{*}} f_{\alpha}\left(Y_{m}, \alpha_{m}\right), \quad \text { where } \alpha \equiv \mu, \lambda, C_{p}, C_{\mathrm{v}} ; \\
& \mu=\left(\frac{T}{273,15}\right)^{3 / 2} \cdot \frac{273,15+C_{S}}{T+C_{S}} \cdot \mu_{0} ; \quad \mu_{T}=\frac{C_{\mu} \cdot \rho \cdot K^{2}}{\varepsilon} ; \quad \lambda_{T}=\frac{C_{p} \cdot \mu_{T}}{\operatorname{Pr}_{\mathrm{T}}} ; \\
& \tau_{i j}=\mu \cdot\left[\left(\frac{\partial u_{i}}{\partial x_{j}}+\frac{\partial u_{j}}{\partial x_{i}}\right)-\frac{2}{3} \cdot \delta_{i j} \cdot \frac{\partial u_{k}}{\partial x_{k}}\right] ; \quad S c_{m}=\frac{\mu}{\rho \cdot D_{m}} ; \\
& G=\mu_{T} \cdot\left\{\frac{1}{2} \cdot\left(\frac{\partial u_{i}}{\partial x_{j}}+\frac{\partial u_{j}}{\partial x_{i}}\right)^{2}-\frac{2}{3} \cdot\left(\frac{\partial u_{k}}{\partial x_{k}}\right)^{2}\right\}-\frac{2}{3} \cdot \rho \cdot K \cdot \frac{\partial u_{k}}{\partial x_{k}},
\end{aligned}
$$

where $t$ is time; $\frac{D(\ldots)}{D t} \equiv \frac{\partial(\ldots)}{\partial t}+\overrightarrow{\mathbf{V}} \cdot \vec{\nabla}(\ldots)$ is the substantial derivative of the scalar function; the notation of the substantial derivative of the scalar function means substantial differentiation of vector function components; $\overrightarrow{\mathbf{V}}$ is the velocity of the atmospheric air and fuel vapors mixture with 
components $u_{1}, u_{2}, u_{3} ; \vec{\nabla}$ is nabla; $Y_{m}=\rho_{m} / \rho$ is the relative mass fraction of the $m$-th component (here, for example, assignment of $m=1 \equiv " v a p "$ corresponds to liquid fuel vapors, $m=2 \equiv "$ air" - to the air (oxidant), $m=3 \equiv "$ prod" - to combustion products); $\mu$ is the coefficient of dynamic viscosity; $\mu_{T}$ is the coefficient of turbulent viscosity; Sc is the Schmidt number; $\xi_{\text {air }}^{\text {mass }}$ is the mass stoichiometric coefficient of the air; $\omega_{\text {vap }}$ is the velocity of chemical reaction; $A, B$ are specified constants of the diffusion model of gas combustion; $\varepsilon$ is the velocity of turbulent kinetic energy dissipation; $K$ is turbulent kinetic energy; the subscript «atm» means the parameter belongs to undisturbed atmosphere parameters; $\overrightarrow{\mathbf{g}}$ is the gravitational acceleration; $P$ is the piezometric pressure of mixture; $\boldsymbol{\tau}$ is the viscous stress tensor with components $\tau_{i j} ; H=h+0,5 \cdot \overrightarrow{\mathbf{V}} \cdot \overrightarrow{\mathbf{v}}$ is total enthalpy ( $h=c_{p}^{v a p} \cdot T$ is total enthalpy in case of perfect gas); $Q_{\text {comb }}$ is the specific (per mass unit) heat of fuel combustion; $S_{\text {rad }}$ is the radiation source term; $\partial Q / \partial t$ is the specified per-unit-volume velocity of heat radiation of outside sources (the specified per-unit-volume capacity of the heat sources); $\lambda_{T}$ is the coefficient of turbulent heat conductivity of the mixture; $e_{m}$ is the internal energy of a unit mass of the $m$-th component; $N^{*}$ is the number of components in the gaseous mixture, $N^{*}=3$ in the particular case; $\operatorname{Pr}$ is the specified Prandtl number (the subscript $\langle K »$ means that the value of the Prandtl number is specified expressly for the equation of turbulent energy (13), subscript $《 \varepsilon »$ is for the equation of turbulence dissipation (14)); subscript « $T$ », when placed beside parameters, means "turbulent"; $G$ is the dissipation function of turbulent flow, expressing a thermal equivalent of mechanical power expendable in the process of gaseous mixture deformation due to its viscosity; $C_{i}, \quad i=\overline{1,4}$ are the specified constants; $L^{*}$ is the quantity of incandescent gases under study (e.g., gaseous combustion products); $\varphi_{j}\left(Y_{j}\right)$ is the specified weighting function; $v$ is the frequency of radiation; $\pi$ is the Pythagorean number; $\chi_{v, j}$ is the absorptivity of radiation by the $j$-th gas; $I_{v b}(T)$ is the spectral intensity of blackbody radiation under the temperature $T$ in vaccum; $I_{v, j}$ is the spectral intensity of radiation of the $j$-th combustion product at a point with the coordinate $s\left(j=\overline{1, L^{*}}\right)$; $s$ is the path length (coordinate) measured along the radiation propagation 
$\overrightarrow{\boldsymbol{\theta}} ; \overrightarrow{\boldsymbol{\theta}}$ is the direction of the radiation propagation; $c_{r a d}$ is the velocity of the radiation propagation in the medium; $\beta_{v, j}$ is the spectral coefficient of the radiation dissipation by the $j$-th gas; $\overrightarrow{\boldsymbol{\theta}}^{\prime}$ is the guide axis of the solid angle $d \vartheta^{\prime} ; R_{0}$ is the universal gas constant; $M_{m}$ is the molar mass of the $m$-th component; $x_{1}, x_{2}, x_{3}$ are coordinates of the radius-vector of point $\left(x_{3}\right.$ is a coordinate on the vertical axis directed away from the center of the Earth); $x_{3,0}$ is a fixed coordinate corresponding to the sea level; $f_{\alpha}(\ldots)$ are known semiempirical functions; $C_{S}$ is the Sutherland constant; $\mu_{0}$ is the coefficient of dynamic viscosity under normal conditions; $C_{\mu}$ is the specified constant; $\delta_{i j}$ is the Kronecker symbol; $D_{m}$ is the coefficient of binary diffusion in the mixture.

It should be noted here that the Reynolds equations (6-20) use averaged parameters of the gaseous mixture flow. At that, the velocity components and the thermal variables $(H, h, T)$ are averaged according to Favre (i.e., using the mixture density as a weighting function), and the density and pressure - according to the classical Reynolds averaging [1]. Such a scheme of averaging is effective as applied to simulation of flows of a compressible gaseous mixture. It should be noted here that, to enhance the accuracy of simulation, it would be well to use the equation written for averaging of the reaction velocity, rather than the equation (10). The mechanism of such averaging using a statistical approach is set forth in [10]. The use of such an approach results in incorporation of a new probability-density function transfer equation into the set (6-20), which significantly complicates solution of practical problems (at the present stage of development and availability of computer machines, this renders solution of industrial problems facing fuel and power facilities unpractical). For this reason, in this case we have to agree to a lower adequacy of simulation of combustion processes and use the equation (10).

The set of equations (6-20) is supplemented by relevant boundary conditions depending on the specific statement of the problem. Recommendations on the appropriate formation of boundary conditions are given in [7]. This set of equations is solved by the finite volume method or the finite element method [11].

The most adequate and consistent procedure for numerical evaluation of a contribution by the radiation energy transfer to the plume parameters variation amounts to solution of integro-differential equations of epy radiant energy transfer (16) for each of the gaseous combustion products. It should 
be noted here that, in the equations (16) being considered, we can disregard the first term compared to other terms, because of the greater velocity of the radiation propagation. In numerical analysis of fire parameters for the integration of functions containing the spectral indicatrix of dissipation $\gamma_{v, j}\left(\overrightarrow{\boldsymbol{\theta}}, \overrightarrow{\boldsymbol{\theta}}^{\prime}\right)$, we use its Legendre polynomial expansion. At that, solution of the equations (16) is carried out by the Monte-Carlo method, the modified method of average flows, or the method of a weighted sum of grey gases [3].

Ignition of the air-and-fuel mixture is simulated using a thermal model of ignition, whose application algorithm is described in details in [7]. The equations (6-20) can be easily extended to the case of analysis of multistage chemical reactions subject to combustion products dissociation involving energy consumption.

\section{On the question of evaluating pool fire duration.}

In analysis of the mechanisms of pool fire extinction, it is required to evaluate the quantity of liquid fuel infiltrated into the soil, and the geometry of the zone of its infiltration into the soil layer. To solve the problem posed, we use numerical analysis of parameters of isothermal single-phase gravity filtration of non-compressible viscous chemically inert liquid into a nondeformable layer of soil. The viscosity of the liquid is assumed to be constant in this case. Taking into account analysis of actual emergency situations, the duration of the spilling process is assumed to be much shorter than that of the filtration process. Such an assumption allows the simulation to separate the processes of spilling and filtration, which enables us to omit solution of the conjugate problem.

In case of the isothermal single-phase gravity filtration of viscous liquid into an isotropic porous medium, the defining equations are set in the form of [5]:

$$
\begin{aligned}
& \frac{\partial\left(m_{\text {soil }} \cdot \rho_{l}\right)}{\partial t}+\vec{\nabla} \cdot\left(\rho_{l} \cdot \overrightarrow{\mathbf{\omega}}\right)=\Omega ; \\
& \overrightarrow{\boldsymbol{\omega}}=-\frac{k_{\text {soil }}}{\mu_{l}} \cdot\left(\vec{\nabla} p+\rho_{l} \cdot \overrightarrow{\mathbf{g}}\right) ; \\
& \rho_{l}=\rho_{l}(p) ; \quad m_{\text {soil }}=m_{\text {soil }}(p) ; \quad k_{\text {soil }}=k_{\text {soil }}(p) ; \quad \mu_{l}=\mu_{l}(p),
\end{aligned}
$$


where $m_{\text {soil }}$ is the porosity of the soil layer; $\rho_{l}$ is liquid (fuel); $\overrightarrow{\boldsymbol{\omega}}$ is the rate of liquid infiltration into the soil layer; $\Omega$ is the source (outflow) of liquid in the soil layer (e.g., resulting from a chemical reaction); $k_{\text {soil }}$ is the coefficient of soil layer permeability; $\mu_{l}$ is the coefficient of liquid dynamic viscosity; $p$ is the filtration (static) pressure. The equation (21) expresses the mass conservation law, and the equation (22) is set by the Darcy law. The type of parameters functional dependencies on the filtration pressure (23) is assumed to be known.

Subject to the above simplifications and assumptions, the set (21-23) will look as follows:

$$
\begin{aligned}
& \vec{\nabla} \cdot \overrightarrow{\mathbf{\omega}}=0 ; \\
& \overrightarrow{\mathbf{\omega}}=-\frac{k_{\text {soil }}}{\mu_{l}} \cdot\left(\vec{\nabla} p+\rho_{l} \cdot \overrightarrow{\mathbf{g}}\right) ; \\
& \rho_{l}=\text { const } ; \quad m_{\text {soil }}=\text { const } ; \quad k_{\text {soil }}=\text { const } ; \quad \mu_{l}=\text { const } .
\end{aligned}
$$

In this set of equations, the target parameters are velocity vector components and the filtration pressure. The density of liquid, the porosity of the soil layer, the coefficient of its permeability, and the coefficient of dynamic viscosity of liquid are predetermined values. In simulation of the liquid fuel filtration through an anisotropic medium, the equation (25) is substituted with the equation [5]:

$$
\omega_{i}=-\frac{k_{\text {soil }, i j}}{\mu_{l}} \cdot\left(\frac{\partial p}{\partial x_{j}}+\rho_{l} \cdot g_{j}\right), \quad i, j=1,2,3
$$

After the set of equations (24-26) (or $(24,26,27)$ ) is closed by relevant boundary conditions, it can be solved by the method of finite differences or the method of finite elements [11].

\section{Certain examples of practical application}

Fig. 1 shows photographs of actual flames of an isooctane fire set in laboratory conditions and provides an example of results of their numerical simulation: a) is a photograph of fire without wind; b) is the isosurface of relative mass fractions of isooctane vapors, corresponding to the highestrate reaction in the air-and-fuel mixture combusting without wind 
(stoichiometric mass fraction); c), d) and e) are combustion with a side wind having a speed of $0.05 \mathrm{~m} / \mathrm{s}$. The simulation used a global exothermal singlephase irreversible reaction of isooctane vapors combustion in the air. The isooctane physical and chemical properties used for calculations have been borrowed from [7]. The differences between the geometric parameters of fire obtained in a numerical experiment and measured in a full-scale experiment are presented in Table 1.

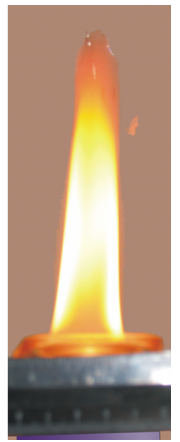

a)

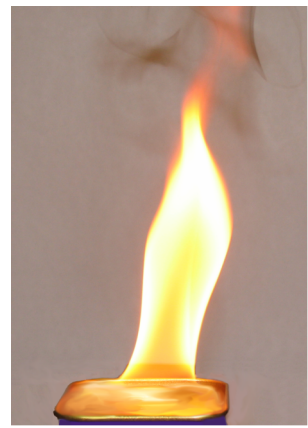

c)

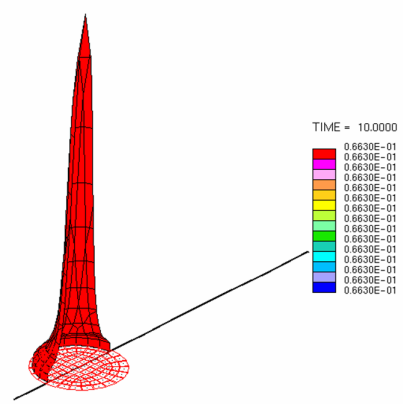

b)

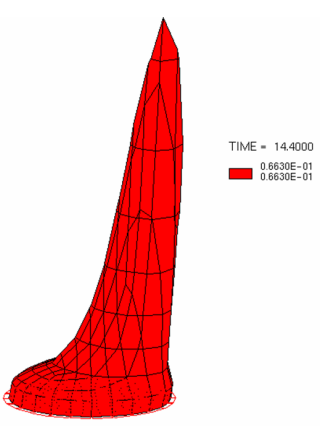

d)

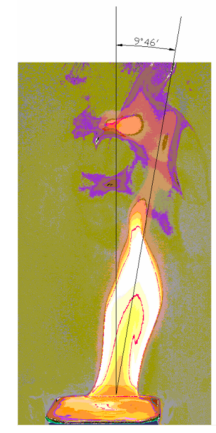

e)

Fig. 1. Example simulation of an isooctane pool fire 
Table 1. Comparison of full-scale measurements and results of numerical simulation of an isooctane fire

\begin{tabular}{|lccc|}
\hline \multicolumn{1}{|c}{ Parameter } & Experiment & $\begin{array}{c}\text { Numerical } \\
\text { calculation }\end{array}$ & $\begin{array}{c}\Delta, \\
\mathbf{\%}\end{array}$ \\
\hline Fire length $L, m$ & 0.115 & 0.128 & 10.2 \\
\hline $\begin{array}{l}\text { Fire width } W \text { at a level of } 0.01 m \\
\text { from the liquid surface, } m\end{array}$ & 0.032 & 0.026 & 23.1 \\
\hline $\begin{array}{l}\text { Angle } \theta \text { of fire vertical deviation } \\
\text { under a wind of } 0.05 m / s, \text { radian }\end{array}$ & 0.1651 & 0.2765 & 40.3 \\
\hline
\end{tabular}

An example of simulation of a full-scale pool fire of spilled gasoline is given in Fig. 2: a) is the isosurface of relative mass fractions of gasoline, corresponding to the highest-rate reaction in the air-and-fuel mixture combusting under a wind load (stoichiometric mass fraction); b) is the isosurface of the temperature field.

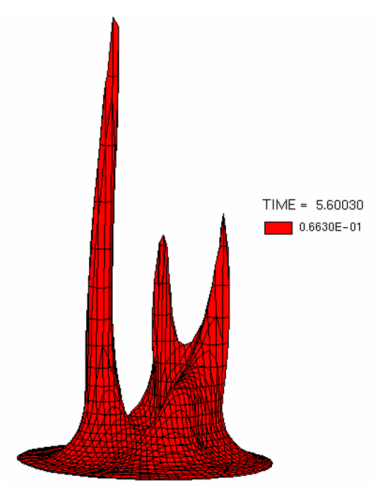

a)

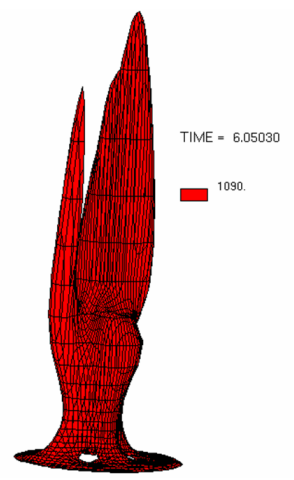

b)

Fig. 2. Example simulation of the time history of a gasoline fire caused by a gas station accident

\section{Conclusion}

The above practical method for numerical evaluation of parameters of pool fires caused by pipeline or storage tank failures can be successfully applied in fire and industrial safety analysis of gas, oil and chemical facilities transmitting or consuming flammable liquids.

At that, results of numerical analysis are used for validation of the geometry 
and sizes of sanitary protection zones, as well as for investigation of causes and development mechanisms of fires. It should be noted that practical application of this method is well supported by software available in the market, e.g. $[2,9]$.

\section{References}

1. Anderson D.A., Tannechill J.C., Pletcher R.H. Computational fluid mechanics and heat transfer. Hemisphere Publishing Copporation, 1984.

2. ANSYS CFX-Solver, Release 10.0: Theory. ANSYS Inc., 2005.

3. Hottel H.C., Sarofim A.F. Radiative Transfer. New York, VcGraw-Hill, 1967.

4. Kays W.M., Grawford M.E. Convective heat and mass transfer: Third Edition. McGraw-Hill, Inc., 1993.

5. Schelkachev V.N., Lapuk B.B. Underground hydraulics. Izhevsk, Regular and chaotic dynamics, 2001. (Russian language)

6. Seleznev V.E., Aleshin V.V. Numerical analysis of fire risk at pipeline systems of industrial power facilities. Int. J. Pressure Vessels and Piping 2006, 83(4), 299-303.

7. Seleznev V.E., Aleshin V.V., Il'kaev R.I., Klishin G.S. Numerical simulation of gas pipeline networks: theory, computational implementation, and industrial applications (Ed. by V.E. Seleznev). Moscow, KomKniga, 2005.

8. Spalding D.B. Combustion and mass transfer. Pergamon Press, 1979.

9. Star-CD version 3.26: Methodology. CD adapco, UK, 2005.

10. Warnatz J., Maas U., Dibble R.W. Combustion: physical and chemical fundamentals, modeling and simulations, experiments, pollutant formation. Springer, 2001.

11. Zienkiewicz O.C., Taylor R.L. The Finite Element method. In three volumes, fifth edition. Oxford, Butterworth-Heinemann, 2000. 3 Vols. 


\section{ПРАКТИЧЕСКИЙ МЕТОД ЧИСЛЕННОГО ОЦЕНКИ ПАРАМЕТРОВ ПОЖАРОВ РАЗЛИТИЯ НА МАГИСТРАЛЬНЫХ НЕФТЕПРОВОДНЫХ СЕТЯХ}

\section{1. Постановка задачи}

Данная статья является логическим продолжением описания практических методов математического моделирования пожаров на объектах газовой и нефтяной промышленности, начатого в [6]. Как известно, горение жидкости, разлитой по прилегающей к зоне разрушения трубопровода (или резервуара хранения) местности, представляет собой горение струи ее пара в воздухе. Поток пара в пламени поддерживается благодаря непрерывно идущему испарению, скорость которого определяется мощностью теплового потока от пламени к жидкости. Кислород, необходимый для горения, поступает в зону реакции из окружающей атмосферы. Пламя при горении жидкости можно отнести к диффузному типу пламён. Таким образом, горение жидкости при моделировании целесообразно рассматривать как специфический случай испарения с последующим горением не перемешанных газов (пара и окислителя) [8].

Высокоточное моделирование пожаров разлития является крайне трудной задачей из-за сложности и многообразия физико-химических процессов, сопровождающих возможное формирование гомотермического слоя в жидкости, кипение и испарение топлива, его возможное разбрызгивание, зажигание и горение паров горючей жидкости. Механизмы этих процессов могут существенно варьироваться в зависимости от типа топлива, состояния и типа грунта в зоне аварии, погодных условий и т.д. В данной статье описывается метод численного моделирования горения жидкостей, транспортируемых по трубопроводам и/или содержащихся в резервуарах хранения на объектах газовой и нефтяной промышленности, с целью проведения оценочных расчетов параметров реальных или возможных пожаров разлития.

При решении задачи полагается, что разлитие горючей жидкости произошло на местности с пористым грунтом. Параметры пятна разлития на местности считаются известными. В первом приближении при моделировании условно не рассматривается фаза прогрева 
топлива. Химические реакции горения считаются бесконечно быстрыми.

\section{2. Моделирование фазы испарения топлива}

Жидкое топливо испаряется в газовую фазу и образуется горючая смесь. При оценочном моделировании испарения топлива принимаются следующие необходимые упрощения и допущения (см. [8]):

- предполагается квазистационарность состояния топлива и окружающей среды при испарении;

- процессы переноса тепла и массы считаются идентичными (число Льюиса равно единице);

- для смеси атмосферного воздуха с парами топлива принимается постоянство коэффициента теплопроводности $\lambda$, произведения плотности смеси $\rho$ и коэффициента бинарной диффузии паров топлива в атмосферном воздухе $D_{n a p}$, а также их независимость от температуры $T$;

- принимается постоянство и независимость от температуры удельной теплоемкости паров топлива $c_{p}^{n a p}$;

- пары топлива диффундируют в стоячем воздухе по вертикальной координатной оси $O z$, направленной от центра Земли;

- величина диффузионного массового потока $(J=\rho \cdot w)$ имеет конечное значение лишь для паров топлива, т.е. $J=J_{n a p}$, где $w-$ проекция средней скорости центра масс смеси паров топлива и атмосферного воздуха на координатную ось $O z$ ( $w$ - это единственная ненулевая проекция данной скорости); обычно такой поток в механике жидкостей и газов называют конвективным, в нашем случае его название было изменено в соответствии с физикой процессов испарения и рекомендациями работы [8];

- работа сдвиговых напряжений и кинетическая энергия пренебрежимо малы;

- внешние объемные источники энергии в зоне испарения топлива отсутствуют;

- воздух не растворяется в топливе;

- химических реакций при испарении не происходит. 
Испарение разлившегося жидкого топлива является вариантом известной задачи о стефановском потоке. Для постановки и решения данной задачи запишем уравнение неразрывности для пара жидкого топлива в диффузионном приближении с учетом принимаемой квазистационарности процесса испарения и перечисленных выше допущений:

$\rho \cdot w \cdot \frac{d Y_{\text {nap }}}{d z}-\rho \cdot D_{\text {nap }} \cdot \frac{d^{2} Y_{\text {nap }}}{d z^{2}}=0$

где $Y_{\text {nар }}$ - относительная массовая концентрация паров топлива; $z-$ пространственная координата на вертикальной оси $O z$. В качестве граничных условий этой задачи принимаются:

$$
\begin{aligned}
& \text { при z }=0: \quad Y_{\text {nap }}=Y_{\text {nap }, 0}=Y_{\text {nap }, \text { нас }} ; \\
& \text { приz }=l: \quad Y_{\text {nap }}=Y_{\text {nap }, l}=Y_{\text {nap }, \text { cmex }} \text {, }
\end{aligned}
$$

где $z=0$ - уровень свободной поверхности топлива; $Y_{\text {пар,нас }}-$ относительная массовая концентрация паров топлива при насыщении; $z=l-$ уровень фронта горения над топливом; $l$ - толщина газовой прослойки между свободной поверхностью топлива и фронтом горения; $Y_{\text {nap,cmex }}$ - известная относительная массовая концентрация паров топлива в их стехиометрической смеси с воздухом.

Проведем первое интегрирование уравнения (1) с учетом принятых упрощений и допущений:

$$
\rho \cdot w \cdot Y_{\text {nap }}-\rho \cdot D_{\text {nap }} \cdot \frac{d Y_{\text {nap }}}{d z}=\text { const }=\rho \cdot w
$$

или

$$
\rho \cdot D_{\text {nap }} \cdot \frac{d Y_{\text {nap }}}{d z}=\rho \cdot w \cdot\left(Y_{\text {nap }}-1\right)
$$

Второе интегрирование уравнения (1) дает следующее решение: 
$\ln \left(Y_{\text {nap }}-1\right)=\frac{\rho \cdot w \cdot z}{\rho \cdot D_{\text {nap }}}+$ const.

Использование граничных условий (2) приводит к тому, что

$\ln \left(Y_{\text {nар,нас }}-1\right)=$ const

и

$\ln \left(Y_{\text {nap }, \text { cmex }}-1\right)=\frac{\rho \cdot w \cdot l}{\rho \cdot D_{\text {nap }}}+$ const.

Тогда,

$\frac{\rho \cdot w \cdot l}{\rho \cdot D_{\text {nap }}}=\ln \left(\frac{1-Y_{\text {nap }, \text { cmex }}}{1-Y_{\text {nap }, \text { нас }}}\right)$.

Таким образом, мы получаем оценку диффузионного массового потока паров топлива в зону горения в виде:

$$
J_{\text {nap }}=\rho \cdot w=\frac{\rho \cdot D_{\text {nap }}}{l} \cdot \ln \left(\frac{1-Y_{\text {nap }, \text { cmex }}}{1-Y_{\text {nap }, \text { нас }}}\right) .
$$

Несмотря на всю очевидность описанного выше подхода к моделированию процессов испарения топлива, с практической точки зрения оценка потока паров топлива в зону горения (3) является малопривлекательной из-за сложности определения параметров $l$ и $Y_{\text {nар,нас }}$. Здесь следует подчеркнуть, что величина $Y_{\text {nар,нас }}$ существенно влияет на процесс испарения и зависит от температуры [8]. Поэтому получим оценку диффузионного массового потока паров топлива в зону горения другим способом. Запишем с учетом сделанных выше допущений и упрощений модификацию известного уравнения энергии [4]:

$-\lambda \cdot \frac{d^{2} T}{d z^{2}}+\rho \cdot w \cdot c_{p}^{n a p} \cdot \frac{d T}{d z}=0$. 
Первое интегрирование (4) дает:

$\lambda \cdot \frac{d T}{d z}-\rho \cdot w \cdot c_{p}^{n a p} \cdot T=-Q_{0}-\rho \cdot w \cdot c_{p}^{n a p} \cdot T_{0}$

или

$\frac{d T}{d z}=\frac{1}{\lambda} \cdot\left[\rho \cdot w \cdot c_{p}^{n a p} \cdot\left(T-T_{0}\right)-Q_{0}\right]$

где $Q_{0}$ - тепловой поток к поверхности топлива; $T_{0}$ - температура на поверхности топлива. Интегрируя второй раз, получим:

$\ln \left[T-T_{0}-\frac{Q_{0}}{\rho \cdot w \cdot c_{p}^{n a p}}\right]=\frac{\rho \cdot w \cdot c_{p}^{n a p} \cdot z}{\lambda}+$ const.

Подстановка граничных условий $\quad\left(n p u \quad z=0: \quad T=T_{0}\right) \quad$ и (при $\left.z=L: \quad T=T_{L}\right)$ позволяет записать:

const $=\ln \left[-\frac{Q_{0}}{\rho \cdot w \cdot c_{p}^{n a p}}\right] ; \quad \ln \left[1-\frac{c_{p}^{n a p} \cdot\left(T_{L}-T_{0}\right)}{Q_{0} / \rho \cdot w}\right]=\frac{\rho \cdot w \cdot c_{p}^{n a p} \cdot L}{\lambda}$,

где $L$ - некоторое известное расстояние в расчетной области (см. ниже).

Ранее отмечалось, что в первом приближении мы пренебрегаем процессами прогрева топлива. Тогда можно считать, что в модельном пожаре разлития свободная поверхность топлива от начала пожара до момента исчерпания запасов горючей жидкости имеет температуру, равную температуре кипения $T_{\text {кип }}$ этой жидкости. Это вполне допустимо, т.к. в фазе прогрева топлива энергия передается в его поверхностный слой до тех пор, пока он не достигнет температуры кипения [10]. Подвод тепла в жидкость от грунта или других источников, не связанных с пламенем, здесь не учитывается. В таком случае можно записать, что $\left(Q_{0}=-\rho \cdot w \cdot q_{0}\right)$, где $q_{0}$ - скрытая теплота испарения топлива (см. [8]). В результате мы получаем оценку диффузионного массового потока паров топлива в зону горения в виде: 


$$
J_{\text {nap }}=\rho \cdot w=\frac{\lambda}{L \cdot c_{p}^{\text {nap }}} \cdot \ln \left[1+\frac{c_{p}^{\text {nap }} \cdot\left(T_{L}-T_{\text {кии }}\right)}{q_{0}}\right] .
$$

Температура $T_{L}$ в процессе численного решения задачи сеточными методами, как правило, связывается с изменяющейся во времени температурой смеси паров жидкости и воздуха в узлах пространственной расчетной сетки, ближайших к поверхности топлива со стороны газовой фазы. При расчетах коэффициент теплопроводности $\lambda$ в (5) заменяется коэффициентом эффективной теплопроводности, который рассчитывается по справочным данным и методикам, изложенным, например, в работе [4]. Величины $c_{p}^{\text {nap }}$ и $q_{0}$ являются экспериментальными справочными данными.

При моделировании пожара разлития формула (5) позволяет дать оценку сверху параметрам функционирования источника горючих паров. Получить оценку времени исчерпания запасов разлившейся жидкости при ее интенсивном испарении, зная функциональную зависимость диффузионного массового потока ее паров (5), не представляет труда. Эта оценка необходима для прогнозирования продолжительности пожара.

\section{3. Моделирование фазы горения паров топлива}

На данной стадии проводится численный анализ параметров горения летучих паров жидкости в газовой фазе как предварительно не перемешанной газовой смеси с применением подходов статьи [6]. Здесь используется модель распада турбулентных вихрей, предложенная Д.Б. Сполдингом [8]. С учетом вышесказанного, моделирование фазы горения (в предположении одностадийной необратимой брутто-реакции между парами топлива и окислителем) сводится к численному анализу следующей системы уравнений $[6,7]$ :

$$
\begin{aligned}
& \frac{D \rho}{D t}+\rho \cdot(\vec{\nabla} \cdot \overrightarrow{\mathbf{v}})=0 \\
& \rho \cdot \frac{D Y_{n a p}}{D t}=\vec{\nabla} \cdot\left(\frac{\mu+\mu_{T}}{\mathrm{Sc}_{\text {nap }}} \cdot \vec{\nabla} Y_{\text {nap }}\right)-\omega_{\text {nap }}
\end{aligned}
$$




$$
\begin{aligned}
& \rho \cdot \frac{D Y_{\text {воздух }}}{D t}=\vec{\nabla} \cdot\left(\frac{\mu+\mu_{T}}{\mathrm{Sc}_{\text {воздуx }}} \cdot \vec{\nabla} Y_{\text {воздух }}\right)-\xi_{\text {воздуда }}^{\text {маса }} \cdot \omega_{\text {nар }} ; \\
& Y_{\text {прод_гор }}=1-Y_{\text {nap }}-Y_{\text {воздуx }} \text {; }
\end{aligned}
$$

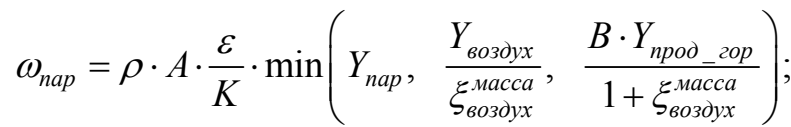

$$
\begin{aligned}
& \rho \cdot \frac{D \overrightarrow{\mathbf{V}}}{D t}=\left(\rho-\rho_{a m n}\right) \cdot \overrightarrow{\mathbf{g}}-\vec{\nabla} P+\vec{\nabla} \cdot\left(\frac{\mu+\mu_{T}}{\mu} \cdot \boldsymbol{\tau}\right)-\frac{2}{3} \cdot \vec{\nabla}(\rho \cdot K) ; \\
& \rho \cdot \frac{D H}{D t}=\frac{\partial P}{\partial t}+Q_{\text {горение }} \cdot \omega_{\text {nар }}-S_{\text {рад }}+\frac{\partial Q}{\partial t}+\rho \cdot \overrightarrow{\mathbf{g}} \cdot \overrightarrow{\mathbf{V}}+ \\
& +\vec{\nabla} \cdot\left(\left(\lambda+\lambda_{T}\right) \cdot \vec{\nabla} T+\frac{\mu+\mu_{T}}{\mu} \cdot \boldsymbol{\tau} \cdot \overrightarrow{\mathbf{V}}-\frac{2}{3} \cdot \rho \cdot K \cdot \overrightarrow{\mathbf{V}}\right)+\sum_{m=1}^{N^{*}} \vec{\nabla} \cdot\left[e_{m} \cdot \frac{\mu+\mu_{T}}{S c_{m}} \cdot \vec{\nabla} Y_{m}\right] ;
\end{aligned}
$$

$\rho \cdot \frac{D K}{D t}=\vec{\nabla} \cdot\left[\frac{\mu+\mu_{T}}{\operatorname{Pr}_{K}} \cdot \vec{\nabla} K\right]+G-\rho \cdot \varepsilon-\frac{\mu_{T}}{\rho \cdot \operatorname{Pr}_{T}} \cdot(\overrightarrow{\mathbf{g}} \cdot \vec{\nabla} \rho) ;$

$$
\rho \cdot \frac{D \varepsilon}{D t}=\vec{\nabla} \cdot\left[\frac{\mu+\mu_{T}}{\operatorname{Pr}_{\varepsilon}} \cdot \vec{\nabla} \varepsilon\right]+\frac{\varepsilon}{K} \cdot\left(C_{2} \cdot G-C_{3} \cdot \rho \cdot \varepsilon-C_{1} \cdot \frac{\mu_{T}}{\rho \cdot \operatorname{Pr}_{T}} \cdot(\overrightarrow{\mathbf{g}} \cdot \vec{\nabla} \rho)\right) ;
$$

$S_{p a d}=\sum_{j=1}^{L^{*}} \varphi_{j}\left(Y_{j}\right) \cdot \int_{v=0}^{\infty} \vec{\nabla} \cdot \overrightarrow{\mathbf{q}}_{v, j}^{r} d v$, где $\quad \vec{\nabla} \cdot \overrightarrow{\mathbf{q}}_{v, j}^{r}=\chi_{v, j} \cdot\left(4 \cdot \pi \cdot I_{v b}(T)-\int_{4 \cdot \pi} I_{v, j}(s, \overrightarrow{\boldsymbol{\theta}}, t) d \vartheta\right) ;$

$$
\frac{1}{c_{\text {излучение }}} \cdot \frac{\partial I_{v, j}(s, \overrightarrow{\boldsymbol{\theta}}, t)}{\partial t}+\overrightarrow{\boldsymbol{\theta}} \cdot \vec{\nabla} I_{v, j}(s, \overrightarrow{\boldsymbol{\theta}}, t)+\left(\chi_{v, j}+\beta_{v, j}\right) \cdot I_{v, j}(s, \overrightarrow{\boldsymbol{\theta}}, t)=
$$

$$
=\chi_{v, j} \cdot I_{v b}(T)+\frac{\beta_{v, j}}{4 \cdot \pi} \cdot \int_{4 \cdot \pi} \gamma_{v, j}\left(\overrightarrow{\boldsymbol{\theta}}, \overrightarrow{\boldsymbol{\theta}}^{\prime}\right) \cdot I_{v, j}\left(s, \overrightarrow{\boldsymbol{\theta}}^{\prime}, t\right) d \vartheta^{\prime}, \quad j=\overline{1, L^{*}} ;
$$

$P=\rho \cdot R \cdot T+\rho_{\text {amu }} \cdot g \cdot\left(x_{3}-x_{3,0}\right) ; \quad R=R_{0} \cdot \sum_{m=1}^{N^{*}} \frac{Y_{m}}{M_{m}} ;$ $H=C_{p} \cdot T+\frac{\overrightarrow{\mathbf{v}} \cdot \overrightarrow{\mathbf{V}}}{2} ; \quad \alpha=\alpha_{\text {смесь }}=\sum_{m=1}^{N^{*}} f_{\alpha}\left(Y_{m}, \alpha_{m}\right), \quad$ где $\alpha \equiv \mu, \lambda, C_{p}, C_{\mathrm{v}} ;$

$$
\mu=\left(\frac{T}{273,15}\right)^{3 / 2} \cdot \frac{273,15+C_{S}}{T+C_{S}} \cdot \mu_{0} ; \quad \mu_{T}=\frac{C_{\mu} \cdot \rho \cdot K^{2}}{\varepsilon} ; \quad \lambda_{T}=\frac{C_{p} \cdot \mu_{T}}{\operatorname{Pr}_{\mathrm{T}}} ;
$$

$$
\tau_{i j}=\mu \cdot\left[\left(\frac{\partial u_{i}}{\partial x_{j}}+\frac{\partial u_{j}}{\partial x_{i}}\right)-\frac{2}{3} \cdot \delta_{i j} \cdot \frac{\partial u_{k}}{\partial x_{k}}\right] ; \quad S c_{m}=\frac{\mu}{\rho \cdot D_{m}} ;
$$


$G=\mu_{T} \cdot\left\{\frac{1}{2} \cdot\left(\frac{\partial u_{i}}{\partial x_{j}}+\frac{\partial u_{j}}{\partial x_{i}}\right)^{2}-\frac{2}{3} \cdot\left(\frac{\partial u_{k}}{\partial x_{k}}\right)^{2}\right\}-\frac{2}{3} \cdot \rho \cdot K \cdot \frac{\partial u_{k}}{\partial x_{k}}$,

где $t \quad-$ время; $\frac{D(\ldots)}{D t} \equiv \frac{\partial(\ldots)}{\partial t}+\overrightarrow{\mathbf{V}} \cdot \vec{\nabla}(\ldots) \quad-$ субстанциональная производная от скалярной функции; запись субстанциональной производной от векторной функции означает субстанциональное дифференцирование компонент векторной функции; $\overrightarrow{\mathbf{V}}$ - скорость смеси атмосферного воздуха с парами топлива с компонентами $u_{1}, u_{2}, u_{3} ; \vec{\nabla}$ - оператор набла; $Y_{m}=\rho_{m} / \rho$ - относительная массовая концентрация $m$-ой компоненты (здесь, например, присвоение $m=1 \equiv "$ nap" соответствует парам топлива, $m=2 \equiv "$ воздуx" - воздуху

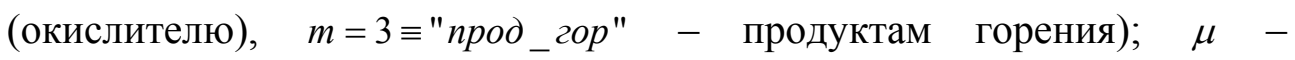
коэффициент динамической вязкости; $\mu_{T}-$ коэффициент

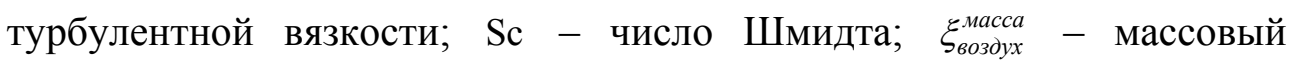
стехиометрический коэффициент воздуха; $\omega_{\text {nар }}-$ скорость химической реакции; $A, B$ - константы диффузионной модели горения газов; $\varepsilon-$ скорость диссипации кинетической энергии турбулентности; $K-$ кинетическая энергия турбулентности; нижний индекс «атм» означает принадлежность параметра к параметрам невозмущенной атмосферы; $\overrightarrow{\mathbf{g}}$ - ускорение свободного падения; $P$ - пьезометрическое давление смеси; $\boldsymbol{\tau}-$ тензор вязких напряжений с компонентами $\tau_{i j}$; $H=h+\frac{\overrightarrow{\mathbf{V}} \cdot \overrightarrow{\mathbf{V}}}{2} \quad-$ полная энтальпия $\left(h=c_{p}^{\text {пар }} \cdot T \quad-\right.$ энтальпия для

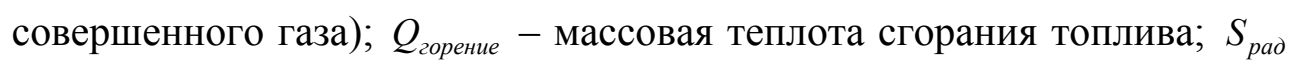
- радиационный источниковый член; $\frac{\partial Q}{\partial t}$ - заданная скорость тепловыделения внешних источников, отнесенная к единице объема (заданная объемная мощность источников тепла); $\lambda_{T}-$ коэффициент турбулентной теплопроводности смеси; $e_{m}$ - внутренняя энергия единицы массы $m$-ой компоненты; $N^{*}-$ число компонент в газовой смеси, в данном случае $N^{*}=3$; $\operatorname{Pr}$ - заданное число Прандтля (нижний индекс «K» означает, что значение числа Прандтля задается специально для уравнения турбулентной энергии (13), нижний индекс 
« $\varepsilon »-$ для уравнения диссипации турбулентности (14)); нижний индекс « $T »$ у параметров означает «турбулентный»; $G$ - диссипативная функция турбулентного течения, выражающая тепловой эквивалент механической мощности, затрачиваемой в процессе деформации газовой смеси вследствие ее вязкости; $C_{i}, i=\overline{1,4}$ - заданные константы; $L^{*}$ - количество рассматриваемых раскаленных газов (например, газообразных продуктов горения); $\varphi_{j}\left(Y_{j}\right)$ - заданная весовая функция; $v$ - частота излучения; $\pi$ - число Пифагора; $\chi_{v, j}-$ спектральный коэффициент поглощения излучения $j$-ым газом; $I_{v b}(T)$ - спектральная интенсивность излучения абсолютного черного тела при температуре $T$ в вакууме; $I_{v, j}-$ спектральная интенсивность излучения $j$-го продукта горения в точке с координатой $s\left(j=\overline{1, L^{*}}\right) ; s$ - длина пути (координата), измеряемая вдоль распространения излучения $\overrightarrow{\boldsymbol{\theta}} ; \overrightarrow{\boldsymbol{\theta}}-$ направление распространения излучения; $c_{\text {излучене }}-$ скорость распространения излучения в среде; $\beta_{v, j}$ - спектральный коэффициент рассеяния излучения $j$-ым газом; $\overrightarrow{\boldsymbol{\theta}}^{\prime}-$ направляющая осевая телесного угла $d \vartheta^{\prime} ; R_{0}$ - универсальная газовая постоянная; $M_{m}$ - молярная масса $m$-ой компоненты; $x_{1}, x_{2}, x_{3}$ - координаты радиус-вектора точки ( $x_{3}$ - координата на вертикальной оси, направленной от центра Земли); $x_{3,0}$ - фиксированная координата, соответствующая уровню моря; $f_{\alpha}(\ldots)$ - известные полуэмпирические функции; $C_{S}-$ константа Сазерленда; $\mu_{0}-$ коэффициент динамической вязкости при нормальных условиях; $C_{\mu}-$ заданная константа; $\delta_{i j}-$ символ Кронекера; $D_{m}-$ коэффициент бинарной диффузии в смеси.

Здесь следует отметить, что в уравнениях Рейнольдса (6-20) используются осредненные параметры течения газовой смеси. При этом компоненты скорости и тепловые переменные $(H, h, T)$ осредняются по Фавру (т.е. с использованием плотности смеси в качестве весовой функции), а плотность и давление - согласно классическому осреднению Рейнольдса [1]. Такая схема осреднения является эффективной для случая моделирования течений сжимаемой смеси газов. Здесь следует отметить, что вместо уравнения (10) для повышения точности моделирования следовало бы использовать 
уравнение, записанное для осредненной скорости реакции. Механизм такого осреднения с использованием статистического подхода изложен в работе [10]. Его применение приводит к появлению в системе (6-20) нового уравнения переноса функции плотности вероятности, что существенно осложняет решение практических задач (на данном этапе развития и доступности компьютерной техники это делает решение производственных задач ТЭК практически невозможным). Поэтому, здесь мы вынуждены идти на снижение адекватности моделирования процессов горения и использовать уравнение (10).

Система уравнений (6-20) дополняются соответствующими краевыми условиями в зависимости от конкретной постановки задачи. Рекомендации по корректному формированию краевых условий содержатся в работе [7]. Решение данной системы уравнений проводится известным методом контрольных объемов [11].

Наиболее адекватный и последовательный путь численной оценки вклада переноса лучистой энергии в изменение параметров факела заключается в решении интегро-дифференциальных уравнений переноса лучистой энергии (16) для каждого из газообразных продуктов горения. Здесь следует отметить, что в рассматриваемых уравнениях (16) можно пренебречь первым членом по сравнению с другими членами из-за большой величины скорости распространения излучения. При численном анализе параметров пожара для интегрирования функций, содержащих спектральную индикатрису рассеяния $\gamma_{v, j}\left(\overrightarrow{\boldsymbol{\theta}}, \overrightarrow{\boldsymbol{\theta}}^{\prime}\right)$, используется ее разложение по полиномам Лежандра. При этом решение уравнений (16) проводится методом Монте-Карло, модифицированным методом средних потоков или методом взвешенной суммы серых газов [3].

Воспламенение топливовоздушной смеси моделируется с использованием тепловой модели зажигания, алгоритм применения которой подробно изложен в [7]. Уравнения (6-20) могут быть легко обобщены на случай анализа многостадийных химических реакций с учетом диссоциации продуктов горения, проходящей с затратой энергии.

\section{4. К вопросу оценки продолжительности пожара разлития}

При анализе механизмов затухания пожаров разлития требуется оценить количество жидкого топлива, просочившегося в почву, и 
геометрию зоны его фильтрации в грунтовый пласт [12]. Для решения поставленной задачи используется численный анализ параметров безнапорной изотермической однофазной фильтрации несжимаемой вязкой химически инертной жидкости в недеформируемом пласте грунта [13]. Вязкость жидкости при этом считается постоянной. Исходя из анализа реальных аварийных ситуаций, длительность процесса разлития предполагается много меньшей, чем процесса фильтрации. Такое предположение позволяет разделить при моделировании процессы разлития и фильтрации, что дает возможность отказаться от решения сопряженной задачи.

В случае безнапорной изотермической однофазной фильтрации вязкой жидкости в изотропной пористой среде определяющие уравнения задаются в виде [5]:

$$
\begin{aligned}
& \frac{\partial\left(m_{\text {пласт }} \cdot \rho_{\varkappa}\right)}{\partial t}+\vec{\nabla} \cdot\left(\rho_{ж} \cdot \overrightarrow{\boldsymbol{\omega}}\right)=\Omega ; \\
& \overrightarrow{\boldsymbol{\omega}}=-\frac{k_{\text {лласт }}}{\mu_{\text {ж }}} \cdot\left(\vec{\nabla} p+\rho_{\varkappa} \cdot \overrightarrow{\mathbf{g}}\right) ; \\
& \rho_{\text {ж }}=\rho_{\text {ж }}(p) ; \quad m_{\text {пласт }}=m_{\text {пласт }}(p) ; \quad k_{\text {пласт }}=k_{\text {пласт }}(p) ; \quad \mu_{\varkappa}=\mu_{\varkappa}(p),
\end{aligned}
$$

где $m_{\text {пласт }}-$ пористость грунтового пласта; $\rho_{\text {ж }}-$ плотность жидкости (топлива); $\overrightarrow{\boldsymbol{\omega}}-$ скорость фильтрации жидкости в грунтовый пласт; $\Omega-$ источник (сток) жидкости в грунтовом пласте (например, из-за химической реакции); $k_{\text {лласт }}$ - коэффициент проницаемости грунтового пласта; $\mu_{ж}$ - коэффициент динамической вязкости жидкости; $p$ фильтрационное (статическое) давление. Уравнение (21) выражает закон сохранения масс, уравнение (22) задается законом Дарси. Вид функциональных зависимостей параметров от фильтрационного давления в (23) считается известным.

С учетом принятых выше упрощений и допущений система (21-23) примет вид:

$$
\begin{aligned}
& \vec{\nabla} \cdot \overrightarrow{\mathbf{\omega}}=0 ; \\
& \overrightarrow{\boldsymbol{\omega}}=-\frac{k_{\text {пласт }}}{\mu_{\varkappa}} \cdot\left(\vec{\nabla} p+\rho_{\varkappa} \cdot \overrightarrow{\mathbf{g}}\right) ; \\
& \rho_{\varkappa}=\text { const } ; \quad m_{\text {пласт }}=\text { const } ; \quad k_{\text {пласт }}=\text { const } ; \quad \mu_{\varkappa}=\text { const } .
\end{aligned}
$$


В данной системе уравнений искомыми параметрами являются компоненты вектора скорости и фильтрационное давление. Плотность жидкости, пористость грунтового пласта, коэффициент его проницаемости и коэффициент динамической вязкости жидкости в данном случае являются заданными величинами. При моделировании фильтрации жидкого топлива через анизотропную пористую среду уравнение (25) заменяется на уравнение [5]:

$$
\omega_{i}=-\frac{k_{\text {nласт }, i j}}{\mu_{\varkappa}} \cdot\left(\frac{\partial p}{\partial x_{j}}+\rho_{\Re} \cdot g_{j}\right), \quad i, j=1,2,3
$$

После замыкания системы уравнений (24-26) (или $(24,26,27))$ соответствующими граничными условиями его решение может проводиться методом конечных разностей или методом конечных элементов. Оригинальный метод решения аналогичных задач фильтрации жидкостей был предложен в работе [11].

\section{5. Некоторые примеры практического применения}

На фиг. 1 представлены фотографии реальных пламен горения разлитого в лабораторных условиях изооктана и примеры результатов их численного моделирования: а - фотография пламени без ветра; 6 изоповерхность относительных массовых концентраций паров изооктана, соответствующая максимально интенсивной реакции в топливовоздушной смеси при горении без ветра (стехиометрическая концентрация); в), г) и д) - горение при боковом ветре со скоростью $0,05 \mathrm{M} / \mathrm{c}$. При моделировании использовалась глобальная экзотермическая одностадийная необратимая реакцией горения паров изооктана на воздухе. Используемые при расчетах физико-химические характеристики данного топлива были заимствованы из [7]. Различия в геометрических параметрах пламени в численном и натурном эксперименте представлены в таблице 1.

Пример моделирования полномасштабных пожаров разлития бензина представлен на фиг. 2: а - изоповерхность относительных массовых концентраций паров бензина, соответствующая максимально интенсивной реакции в топливовоздушной смеси при горении с ветровой нагрузкой (стехиометрическая концентрация); б) изоповерхность температурного поля. 


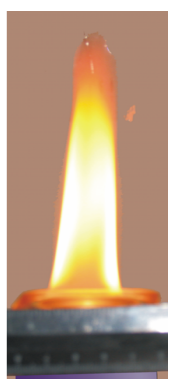

b)

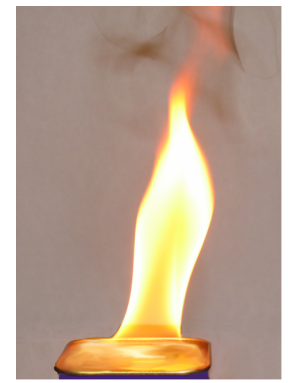

d)

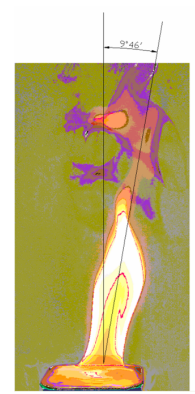

e)

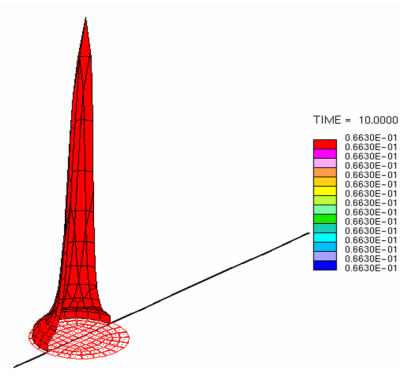

b)

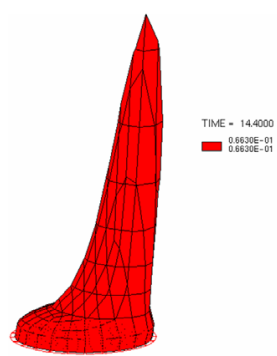

d) 
Практический метод численного оченки параметров.......

Таблица 1. Результаты сравнения натурных измерений и численного эксперимента по горению изооктана

\begin{tabular}{|c|c|c|c|}
\hline Параметр & Эксперимент & $\begin{array}{c}\text { Численный } \\
\text { расчет }\end{array}$ & $\begin{array}{l}\Delta, \\
\%\end{array}$ \\
\hline Длина пламени $L, м м$ & 115 & 128 & 10,2 \\
\hline $\begin{array}{c}\text { Ширина пламени } W \text { на уровне } 10 м м \text { от } \\
\text { поверхности жидкости, } м \text { м }\end{array}$ & 32 & 26 & 23,1 \\
\hline $\begin{array}{c}\text { Угол } \theta \text { отклонения пламени от } \\
\text { вертикали при ветре } 0,05 \text { м/с, градус }\end{array}$ & 9,46 & 15,84 & 40,3 \\
\hline
\end{tabular}

\section{6. Заключение}

Рассмотренный в данной статье практический метод численной оценки параметров пожаров разлития, возникающих при разрушениях резервуаров хранения или трубопроводов промышленных энергетических систем, может успешно применять при анализе пожарной и промышленной безопасности объектов ТЭК, на которых транспортируются или используются горючие жидкости. При этом результаты применения численного анализа используются для обоснования геометрии и размеров санитарно-защитных зон, а также для расследования причин и механизмов развития пожаров $[2,9]$.

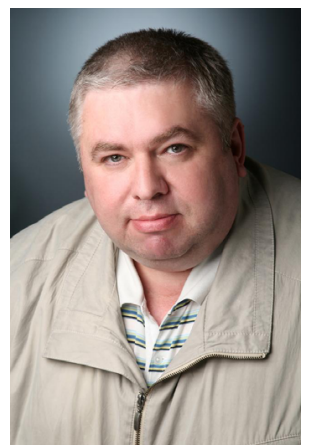

\section{Vadim SELEZNEV, Doctor of Science, Professor}

Vadim Seleznev received his PhD degree from the Russian Federal Nuclear Center - All-Russian Scientific Institute of Technical Physics in Snezhynsk and his DSc degree from Moscow Power Engineering Institute (Technical University). Vadim Seleznev has the Russian State Certificate of Professor. Prof. Seleznev has coauthored 9 books and has over 190 publications on various aspects of computational fluid dynamics, numerical thermal analysis and mathematical optimization. He is past Deputy Chief Designer of the Russian Federal Nuclear Center - All-Russian Scientific Institute of Experimental Physics in Sarov. Currently, Prof. Seleznev is First Deputy Director of the Physical and Technical Center in Sarov, Russia.

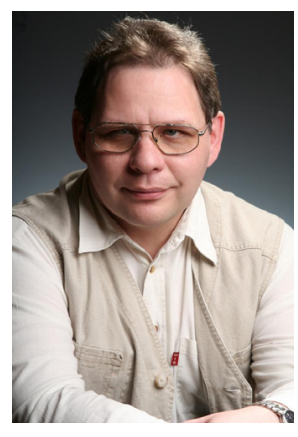

\section{Vladimir ALESHIN, Doctor of Science}

Vladimir Aleshin received his PhD degree from Moscow Power Engineering Institute (Technical University) and his DSc degree from Russian State Academy of Fire Service in Moscow. Dr. Aleshin has coauthored 9 books and has over 130 publications on various aspects of continuum mechanics, numerical structural and thermal analyses. He is past Deputy Chief of Division of the Russian Federal Nuclear Center - All-Russian Scientific Institute of Experimental Physics in Sarov. Currently, Dr. Aleshin is Deputy Director of the Physical and Technical Center in Sarov, Russia. 
